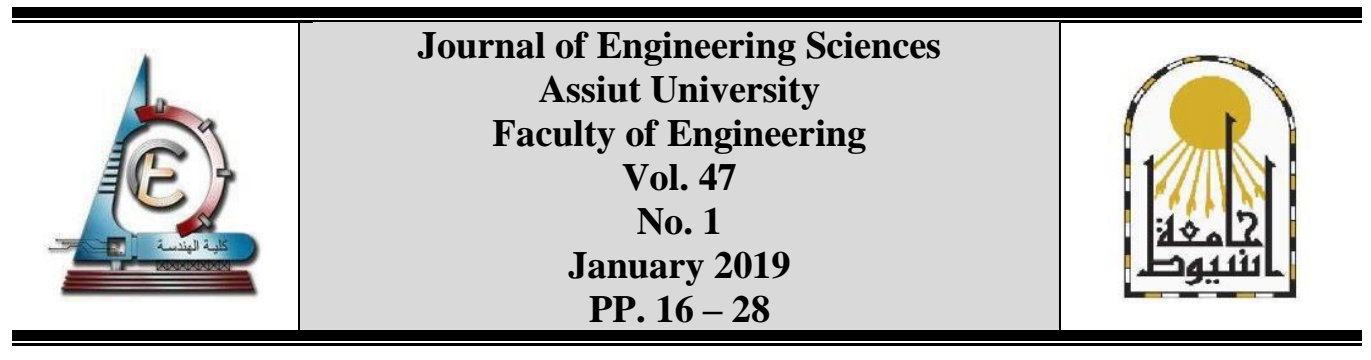

\title{
EVALUATION OF THE NANO CEMENT PRODUCTION FOR CONCRETE STRUCTURES IN EGYPT
}

\author{
Mohamed S. Khalafalla
}

\author{
Construction Research Institute, NWRC
}

Received 14 October 2018; Accepted 4 November 2018

\begin{abstract}
Production of Nano cement using Nanotechnology is considered a new potential approach in the construction material industry. It has the ability to decrease the size of the cement particle to the Nano scale which increases the cement chemical activity. In this technology, high-performance cement is produced while preserving the environment. To evaluate the economics of establishing a Nano cement unit in an existing typical factory in Egypt, the Cement Factories on canal way in Egypt are selected as a case study. The economic indicators used for the evaluation include Net Present Value (NPV), Internal Rate of Return (IRR), and Break Even Point (BEP). The results were used to decide on the feasibility of building Nano cement unit. It was found that Net Present Value has a positive amount between two interest rate $10 \%$ to $30 \%$. The Internal Rate of Return indicator requires increasing the revenue by $38.80 \%$ above the interest rate of Central Bank of Egypt. Finally, Break Even Point is gained before one year of production of 720000 ton annually and within 6 years at variable cost/price. Therefore, establishing the product line of Nano cement in Egypt raises the economic return and enhances the concrete quality.
\end{abstract}

Keywords: Nano cement, cement industry, cement economic.

\section{Introduction}

The harsh environmental conditions that usually face water structures can cause a lot of deterioration problems. Solving these problems may be done through improving the material used in the construction. Cement is the main material of concrete and therefore, cement manufacturing process is very vital for the construction industry. Portland cement clinker manufacturing requires a large amount of energy and produces large amounts of $\mathrm{CO}_{2}$. Hence, one of the strategies to solve these problems is the use of alternate fuels. Nowadays, the main objective of cement industry is to reduce the environmental impact involved in the manufacturing process. Such tasks include reducing $\mathrm{CO}_{2}$ emissions to decreasing energy consumption and improving the clinkerization process efficacy. Nanoparticles may exhibit size-related properties dissimilar from those detected in bulk materials. It considers the bonding the bonding between bulk materials and molecular structures. At nanoscale, the atoms percentage becomes significant providing special properties. 
The development in Nano-technology guided the development of the so-called "Nano Cement". Nano cement can be defined as the cement that has been chemically treated and regrinded to the nanometer scale. Such cement has higher characteristic conditions than the traditional cement. The concrete produced using Nano cement is normally of lesser pores, lower porosity, and consequently better quality. Moreover, Nano cement based-concrete has also higher hydrodynamic resistance to tidal waves. Moreover, Nano cement is a good alternative to grout used for rehabilitation and strengthening of existing structures due to its high compatibility with different surfaces. Nano cement matrix has the ability to produce a higher percentage of calcium silicate hydrate and fill the pores well. For these reasons, it is highly recommended to encourage such a vital industry and focus the research on its development in Egypt.

Nano cement is a modified Portland cement and it makes possible to produce concrete with high strength, water and frost resistance and durability at a high economic efficiency of production and application ${ }^{[1]}$. The obtained performance characteristics of Nano cement are the best in the cement industry history. One of the exclusive properties of Nano cement is the ability to concrete injection and interacts with its components. Therefore, specialized construction companies use Nano cement to repair precast concrete products of large dimensions as shown in Figure $1^{[2]}$. The compressive and flexural strength of concrete with Nano cement after 28 days increase by $60 \%$ and $17 \%$ consecutively, without thermal treatment ${ }^{[2]}$.

Sabdonoa et al. studied the improvement in compressive strength of mortar with Nano cement content ${ }^{[3]}$. Bickbau and Shykun presented the production of ultra-high strength concrete with Nano cement ${ }^{[4]}$. Ikhlef provided results of different tests investigating the mechanical and physical characteristics of mortars and concretes consisting of Nano cement. The results showed improvement of water absorption of mortar and concrete. The compressive strength at 28 days of concrete was increased by $10-65 \%{ }^{[5]}$.

The proved ability of Nano cement to long-term storage without loss of activity is very important. The results of recent testing of fresh and one-year stored Nano cement were recorded. Nano cement can be produced by low-clinker content. The reaction between cement molecular and sand repeatedly depends on the fact that their sizes are nearly equal, so the water content decreases in the system due to configure hydrosilicate. In low-clinker Nano cement, the cement hydration is escorted by the binding of $\mathrm{Ca}(\mathrm{OH}) 2^{[1]}$.

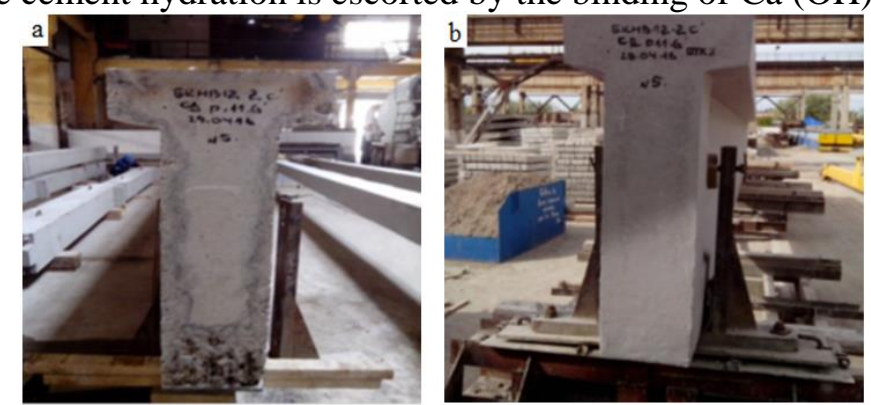

Fig. 1. Repaired precast crane by Nano cement

a. Surface damage b. Crane after repair with Nano cement

It is evaluated that roughly 5 billion tons of cement are produced all over the world every year with a high increment in the demand. Certainly, this massive production of cement has an effect on power generation and quality of environment and therefore requires huge costs. It is important to develop alternative binders which are cost-effective and environmentally friendly. Utilizing nanotechnology for creating Nano cement might be 
considered as a potential approach to achieve that goal. This industrial technology can be reached by decreasing the grain particle of cement to the nanoscale and therefore, increasing the surface area which leads to increase of chemical activity and nucleation effect. Thus, the mechanical strength and durability of concrete will be improved ${ }^{[1]}$.

Bickbau recounted usage of Nano cement to reduce shrinkage and porosity and accordingly increased the long-term durability of concrete ${ }^{[6]}$. From an economic point of view, Bickbau discussed the operation of the low-clinker Nano cement technology and presented that there is a real chance to decrease the cost per unit weight (ton) of cement by $40-60 \mathrm{~kg}$ with the same fuel content. This means the cement manufacture developed without built-up a new stages and the gas emissions reducing by 30 to $40 \%$ per ton ${ }^{[7]}$. In this technology, the amount of carbon dioxide emitting from cement factories is reduced significantly through reduction of the produced cement, therefore, can be more friendly with environment in addition to the quality of produced cement ${ }^{[8]}$. This technology adapts with the special requirements of civil engineering. Depending on structure requirements such as crack resistance, corrosion resistance and mechanical strength, additional material such as Silicon Dioxide nanoparticles (SiO2), Carbon nanotubes and Aluminum Oxide nanoparticles (A12O3) will be mix with clinker to improve the chemical composition of Nano Cement. ${ }^{[9-10]}$.

As in situ cases, ultra-high-performance concretes (UHPC) are Nano optimized materials used in the United States for bridges. Iowa built the first UHPC Bridge in North America in Wapello County. It was a joint project between Wapello County and the DOT.

Currently, there are several trial photocatalytic pavements sections that have been either built or are being planned. One such section using TiO2 is in St. Louis, MO, USA. This pavement is a new highway constructed in 2011.

In 2012, Rusnano Ltd certificate six types of Nano cements to verify a full agreement to produce Nano cement with general purpose. In 2014, the Russian Federation approved Nano modified Portland cement technical conditions and established international patents of Nano cement ${ }^{[11]}$.

The studies above indicated the impacts of Nano cement on the field of concrete manufacturing. Hence, it is necessary to evaluate the economics of this technique as appropriate for the specifications of each country. This paper assesses the suitability of presenting nanotechnology through the Nano cement production unit within an existing cement factory. The feasibility of establishing a production line of Nano cement in typical cement factories on canal way in Egypt, using local silica sand, is being studied.

\section{Material and method}

Nano cement was produced by adding mineral supplement as fly ash and silica or slag sand with crushed modified clinker ${ }^{[12]}$. The moisture content of the mill mixture (Figure 2) was within $3 \%$ using a drying unit. This mill is consisting of two chambers separated by intermediate diaphragm according to the grinding size. At the end of the mill, found outlet diaphragm to control the finial grinding size. The mixing line is grinded for 40 minutes in the mechanochemical mill until producing the Nano cement as a result of chemical activation of modified clinker ${ }^{[7]}$. Figure 3 indicates the chart of Nano cement production steps. For one ton of grind, clinker needs one ton of silica sand and polymeric modifier $(0.6 \%-2.0 \%$ of silica sand additive) in dry form. These simple raw materials used allow overall cost reduction, and it will be a cost-effective line in terms of materials. The mineral is added in $25 \mathrm{~mm}$ diameter and gypsum with $5 \%$ moisture content. Two tons of Nano 
cement is extracted. The power cost for one ton of cement is decreased considering the cost for the additional grinding and energy ${ }^{[7]}$. The clinker modifier (Silica sand and gypsum) takes place to adjust the mix before the burning process.

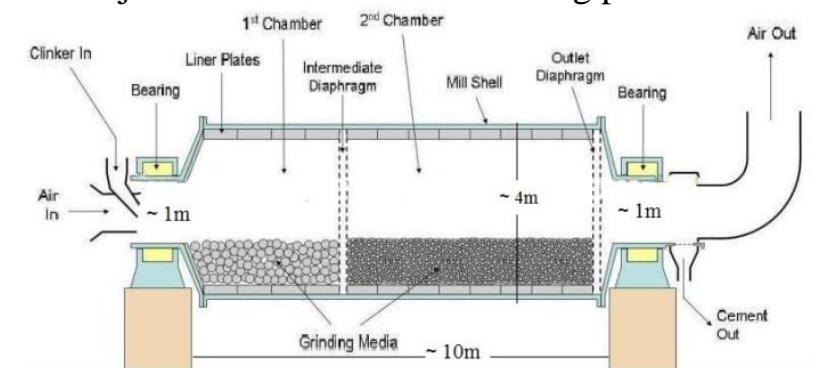

Fig. 2. Turbine ball mill; (Source: http://www.hxjq-crusher.com/products/chinaware-ball-mill.html).

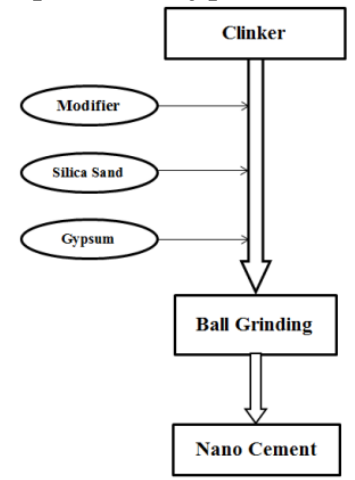

Fig. 3. Flow Chart of Nano-cement Production.

The Nano cement produced is tested in terms of soundness, setting times, fineness and mechanical strength. A channel of experts shall be established to the comprehensive quality control (QC) program. Specific surface area (SSA) of Nano cement proposed is $3.5^{*} 10^{6} \mathrm{~cm}^{2} / \mathrm{g}$ whiles Ordinary Portland Cement SSA $=3112 \mathrm{~cm}^{2} / \mathrm{g}{ }^{[13]}$. The demand proportion depends on the property desired, product quality, and price (which requires government support in early stage of production).

\section{Study plan}

The plan suggests the production of Nano cement for concrete structures especially water structure through improving the production line in typical cement factories on canal way in Egypt. Data collection from these existing factories utilized to analyze the economic indicators of Nano cement production. These factories were chosen because no additional funds are required for producing a new product line and the raw materials are available in the zone of the surrounding mountain area.

\subsection{Materials}

Various materials can supply Nano Cement Line based on the raw material in the factories zone. Sand is used in desert regions while dust and slag are exist in factories region. Egypt is rich in high pure silica sand in the form of quartz mineral which contains a high ratio of silica $(99 \% \mathrm{SiO} 2)$. Sinai is selected as a supply region for raw material since it is near to the factories (about $100 \mathrm{~km}$ ). 10\% clinker will be separated before curing and processing to support Nano cement generator unit. Tables 1 and 2 indicate the characteristics of Sinai sand and clinker cement respectively ${ }^{[5]}$. A polymeric modifier contained $60 \mathrm{wt} \%$ of sodium 
naphthalene sulfonate and mineral silica by $30 \mathrm{wt} \%$. It provides the formation of continuous Nano shells as capsules of Sodium naphthalene sulfonate structured by calcium cations. Sodium naphthalene sulfonate (the addition modifier) is planned to be imported from China. Sinai Company -the nearest factory- is a target to supply gypsum. For one ton Nano cement, the raw materials weight and prices of sources used by Egypt currency (pound) are shown in Table 3. At the time of the study, the total cost of materials was 916 pound per ton.

Table 1.

Sand Chemical Compounds

\begin{tabular}{|l|c|c|c|c|c|c|c|c|}
\hline Oxides & $\mathrm{SiO}_{2}$ & $\mathrm{Fe}_{2} \mathrm{O}_{3}$ & $\mathrm{Al}_{2} \mathrm{O}_{3}$ & $\mathrm{CaO}$ & $\mathrm{MgO}$ & $\mathrm{Na}_{2} \mathrm{O}$ & $\mathrm{K}_{2} \mathrm{O}$ & Losses \\
\hline Weight $\%$ & 99.2 & 0.092 & 0.66 & 1 & 0.04 & 0.04 & 0.03 & 0.4 \\
\hline
\end{tabular}

Table 2.

Chemical and Physical Properties of Portland cement

\begin{tabular}{|l|c|c|}
\hline Property & Unit & Value \\
\hline Loss on Ignition & $\%$ & $\leq 5.0$ \\
\hline Insoluble Residue & $\%$ & $\leq 5.0$ \\
\hline Sulphate (SO3) & $\%$ & $\leq 3.5$ \\
\hline Chloride Content (CL) & $\%$ & $\leq 0.10$ \\
\hline Setting Time (Initial) & $\mathrm{min}$ & $\geq 60$ \\
\hline Soundness (Expansion) & $\mathrm{mm}$ & $\leq 10$ \\
\hline Compressive Strength 2D & $\mathrm{MPa}$ & $\geq 10$ \\
\hline Compressive Strength 28D & $\mathrm{MPa}$ & $\geq 42.5$ \\
\hline
\end{tabular}

Table 3.

Weight and Cost of Raw Material for one Ton Nano Cement

\begin{tabular}{|c|c|c|c|c|c|}
\hline & Clinker & Silica Sand & Gypsum & Modifier & Total \\
\hline Percentage & 74.5 & 20 & 4 & 1.5 & 100 \\
\hline Weight (kg) & 756 & 203 & 40.6 & 15.2 & 1015 \\
\hline Price (Pound) & 733 & 101 & 26 & 56 & 916 \\
\hline
\end{tabular}

\subsection{Ball mill}

China was developing cement production and produced 2.50 billion tons in $2014^{\text {[11] }}$. China is the best choice to import equipment under the condition of prices and quality. A $(4.2 \times 11.0)$ $\mathrm{m}$ ball mill with functioning power and feeding is suitable to fit this task. $800 \mathrm{~kW}$ is the power of motor for 25-130 ton/h. The screen filter passes particles with less than $25 \mathrm{~mm}$ in size into mill. Storage tower stores the feeding materials such as clinker, sand, gypsum. The silos have the ability to store nearly 100 tons. Polyester Fiber is designated as a bag filter for cement dust.

\section{The Costs and revenue of unit}

\subsection{Principal cost}

The initial cost in terms of construction, devices and technicians is the main cost required for this project. Shykun studied the cost of devices ${ }^{[14]}$ and indicated that the devices cost with installation is about 168.5 million LE, as shown in Table 4. Structure with vital facilities and devices are the components that will annually depreciate but require maintenance. Nasr predicted the depreciation annual rate and maintenance between 
Mohamed S. Khalafalla, Evaluation of the Nano cement production for concrete structures........

(5\%-10\%), 3\%-10\% respectively ${ }^{[15]}$. Table 5 indicates the main cost due to the machine consumption and 26.3 million LE is the total annual cost to produce 720000 tons.

Table 4.

Summary of Capital Costs of the Proposed Project

\begin{tabular}{|c|c|c|c|c|}
\hline Elements & $\begin{array}{c}\text { Land, } \\
\text { Structure, and } \\
\text { Facilities }\end{array}$ & $\begin{array}{c}\text { Devices (Ball Mill, } \\
\text { Bunkers, filtration, } \\
\text { and laboratory) }\end{array}$ & $\begin{array}{c}\text { Transport, } \\
\text { Installation and } \\
\text { Operation }\end{array}$ & $\begin{array}{c}\text { Total of } \\
\text { capital fixed } \\
\text { cost }\end{array}$ \\
\hline Cost (Million LE) & Available & 166.75 & 1.75 & 168.5 \\
\hline
\end{tabular}

Table 5.

The Estimated Annual Fixed Financing Cost

\begin{tabular}{|c|c|c|c|c|c|c|}
\hline \multirow{2}{*}{ Elements } & \multicolumn{5}{|c|}{ Land, Structure, and Facilities } & \multirow{2}{*}{ Devices } \\
\cline { 2 - 6 } & \multirow{2}{*}{ Land } & \multirow{2}{*}{ Structure } & \multicolumn{3}{|c|}{ Facilities } \\
\cline { 4 - 6 } & & - & 281400 & 43900 & 26400 & 168500000 \\
\hline Cost & - & - & $5.00 \%$ & $5.00 \%$ & $10.00 \%$ & $5.00 \%$ \\
\hline Consumption rate \% & - & - & $3.00 \%$ & $5.00 \%$ & $10.00 \%$ & $10.00 \%$ \\
\hline Maintenance rate \% & - & - & 22512 & 4390 & 5280 & 25275000 \\
\hline Total Cost & & & Furniture & Air- \\
\hline Total annual Cost & & \multicolumn{5}{|c|}{25307182} \\
\hline Annual insurance & \multicolumn{7}{|c|}{26319469.28} \\
\hline Total Annual Sum Cost & \multicolumn{7}{|c|}{} \\
\hline
\end{tabular}

\subsection{Operating costs}

The production of bill mill is proposed to be $100 \mathrm{t}$ per hour. Therefore, in one day, production line can reach $2400 \mathrm{t}$ depending on 8 hours' work for one shift. Therefore, the production may reach 720,000 ton per year.

Operations, raw material and management costs are the total annual variable costs. One ton of Nano cement costs in range of 1200 1500 LE depending on the variable costs. Gas, power, water, and other services called operational necessities. Depending on the prices in the study period it almost costs 2.44 pound/ton as shown in Table 7 . The raw material required to produce one ton of Nano cement is estimated to be 916 pounds, as detailed in Table 3 and Table 7. The operating staff of the unit is divided into two teams; engineering and technicians while top management in the factory takes charge of management and their salary should be increased. Table 6 indicates the workers required for operation. The range of monthly salary is between 3200 and 12000 pounds depending on the position, therefore, the total annual salaries are estimated to be 2.96 million pounds. 
JES, Assiut University, Faculty of Engineering, Vol. 47, No. 1, January 2019, pp.16-28

Table 6.

The Salary of Board Member ${ }^{[16]}$

\begin{tabular}{|c|c|c|c|c|}
\hline Board Unit & Jobs & No & Salary & Salary/Month \\
\hline \multirow{3}{*}{ Management } & General manager & 1 & 6000 & 6000 \\
\hline & Directors & 1 & 4500 & 4500 \\
\hline & Accountant & 1 & 3500 & 3500 \\
\hline \multirow{3}{*}{ Engineering } & Mechanical Engineer & 3 & 12000 & 36000 \\
\hline & Civil Engineer & 2 & 10000 & 20000 \\
\hline & Chemical Engineer & 2 & 8000 & 16000 \\
\hline \multirow{4}{*}{ Technical } & Technician & 3 & 10000 & 30000 \\
\hline & Technician assistant & 6 & 6500 & 39000 \\
\hline & Skilled Workers & 6 & 9000 & 54000 \\
\hline & Workers & 12 & 3200 & 38400 \\
\hline Service & Guards & available & available & - \\
\hline \multicolumn{4}{|l|}{ Total salary/month } & 247400 \\
\hline Total salary/year & \multicolumn{4}{|c|}{2968800} \\
\hline
\end{tabular}

Table 7.

Annual Variable Cost

\begin{tabular}{|l|c|c|}
\hline \multicolumn{1}{|c|}{ Element } & Cost(L.E)/ton & Cost (Million Pound) \\
\hline Operational & 2.44 & 1.76 \\
\hline Raw Materials & 916.00 & 659.52 \\
\hline Management & 4.12 & 2.97 \\
\hline Consumption \& Maintenance & 36.55 & 26.32 \\
\hline Total Annual variable Cost & 959.12 & 690.57 \\
\hline
\end{tabular}

\subsection{Income}

The proposed price is suggested to be 1500 pound per ton (more than the current price of cement in the market) since the demand will change the price. The marketing depends on how to present Nano cement for concerned partners, consulting bureaus, and construction companies. By this proposed price, Nano cement is competitive with the ordinary Portland cement sold at 1100 LE per ton in the local market at March 2018.

The estimated income for the factory is in the range of 1080 million pounds per year for an estimated 720000 ton/year. The rate of selling gradually increases with the first year at selling rate of $50 \%$, second year $75 \%$, and the third year settles at $100 \%$.

\section{Economic indicator study}

Depending on time value impact, the economical items are discussed to evaluate the financials of the production line.

\subsection{Net present value (NPV)}

The definition of Net Present Value (NPV) is the "the sum of the present value (PV) in terms of revenue and expenses over a specific time" ${ }^{[17]}$.

$N P V=\sum_{t=0}^{t=n} \frac{C_{t}}{(1+r)^{t}}-C_{0}$ 


\section{Where:}

$\mathbf{C} \mathbf{t}=$ Net cash inflow during study period, $\quad \mathbf{t}=$ number of time periods

$\mathbf{r}=$ interest rate

$\mathbf{C}_{\mathbf{0}}$ : total initial investment costs

Depending on the hypothesis of -study period- the cost and revenue per year does not increase as shown in Figure 4. The present value will be an inverse relationship with the years indicated as shown in Figure 5. It indicates the comparison between NPV cost and revenue by $10 \%$ discount. The NPV cost value will be the lowest value after 10 years by 304.03 million LE, whereas the annual revenue is expected to be 458.03 million LE after the same period. Figure 6 indicates NPV cost/revenue comparison with $30 \%$ reduction. It should be noted that after 10 years the lowest cost value will be 67.60 million LE, whereas, the annual revenue will reach 101.84 million LE. The difference between total sum of revenues and cost is positive by (1208.28 million LE) at a discount rate $10 \%$, whereas at $30 \%$ the difference reach (352.24 million LE). This indicates that the project is economically feasible and can make profit.

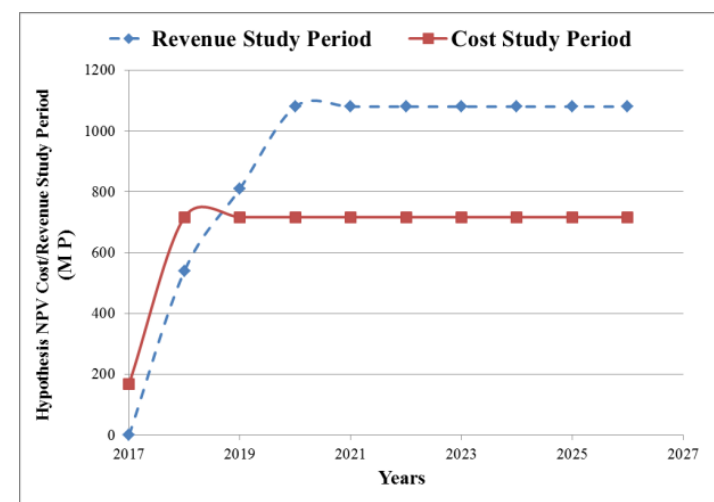

Fig. 4. Hypothesis of NPV Cost/Revenue for Study Period

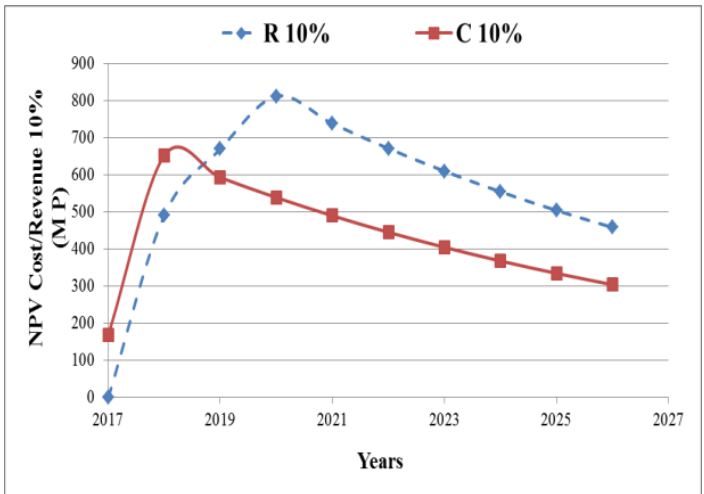

Fig. 5. Hypothesis of NPV Cost/Revenue with $10 \%$ discount 


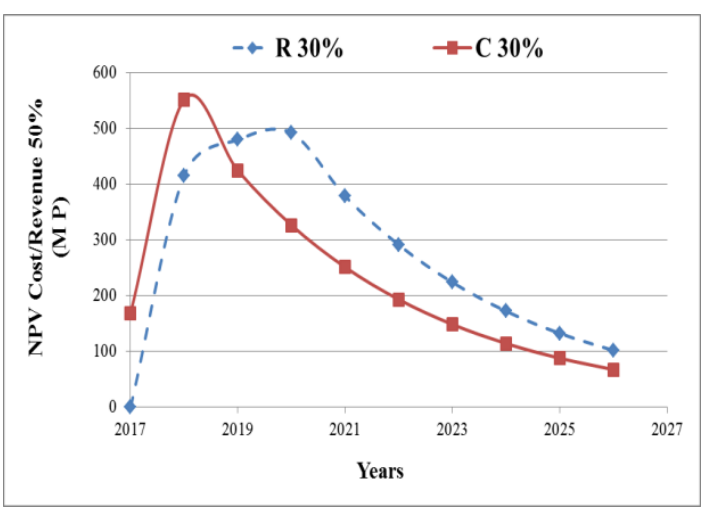

Fig. 6. Hypothesis of NPV Cost/Revenue with $30 \%$ discount

\subsection{Internal rate of return (IRR)}

Internal rate of return (IRR) is an investment indicator. It presents a reduction factor to make the NPV of money stream to be zero ${ }^{[18]}$. On the hypothesis of the Nano cement unit installation in the first year and based on the interest rate in the range of $10 \%$ and $30 \%$, IRR can be calculated from the data given about the unit through fixed cost, variable cost, and revenue and it is found to be $57.55 \%$. This value is considered higher than the interest rate approved by the central bank of Egypt 18.75\% which means that the project is cost-effective.

\subsection{Break - Even point (BEP)}

The point where the cost line intersects with income line is defined as Break-Even Point. This means the project has not suffered any harm or gained any cash (zero profit point). It indicates quantity sold to cover the project $\operatorname{cost}^{[18]}$.

The relation between the accumulative number units and revenue having two scenarios. The first relationship is linear equation. Therefore, 1 year is a long enough period to touch the Break-Even Point, see Equation 2.

$$
\boldsymbol{B E P}=\frac{F C}{(S-V)}
$$

\section{Where;}

$\mathbf{B E P}=$ break - even point;

$\mathbf{F C}=$ total fixed expenses (168.5 million LE)

$\mathrm{S}=$ selling price of a single unit of product $(1500 \mathrm{LE} / \mathrm{Ton})$

$\mathrm{V}$ : variable expenses a single unit of product $(960 \mathrm{LE} / \mathrm{Ton})$

The variable expense $(\mathrm{V})$ is the summation of total annual variable cost form plus the rate of consumption and Maintenance in addition to insurance cost. Depending on the hypothesis of the sale price of a bag that will remain fixed during the study period; the BEP will be achieved after the production of 546000 ton. In summary, the unit can produce 720000 ton/year of Nano cement and the BEP is achieved before 1 year, as shown in Figure 7. 


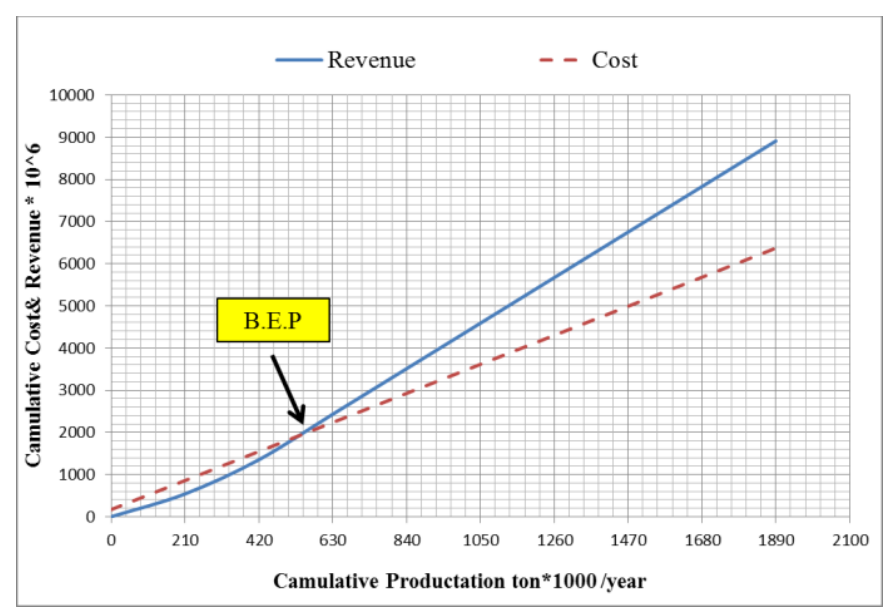

Fig. 7. The Relation between Cumulative Cost and Revenue and Cumulative Production

The variation in production cost and income value annually is the second scenario to assess the feasibility of Nano cement unit. The variable demand is the main factor affecting the sale price of Nano cement which is strongly reflected on the price range from 1200 to 1500 pound. While, the change cost of operation, materials and employees' salaries reflect the variable cost of the ton in range of 959 to 1343 pound. The expected regularly change in sale price and cost is indicated in Table 8 (with regards to the consumption and maintenance of capital cost). Therefore, a nonlinear relationship between cumulative cost and sale price is created. Whereas the demand establishes a low rate, the expected return will rise depending on only high sale prices. On the other hand, the cost will rise gradually as shown in Figure 8, thus; one year is enough to observe the first BEP. Later, the profit will continue rising for almost 6 years until reaching the second BEP. The production cost and sale price are presented by second-order polynomial equations in equations No 3 and 4 respectively depending on Table 8 and Figure 8. The curves indicate the cost will continue to rise after the second BEP but this is not true because the fixed cost has faded.

Table 8.

Expected Data toward Variable Cost and Revenue

\begin{tabular}{|c|c|c|c|c|c|c|}
\hline Time (years) & price /ton & Cost/ton & Demand & Cumulative & $\begin{array}{c}\text { Total } \\
\text { Cost }\end{array}$ & $\begin{array}{c}\text { Total } \\
\text { revenue }\end{array}$ \\
\hline 0 & 1500 & 0 & 0 & 0 & 169 & 0 \\
\hline 1 & 1500 & 959 & 576000 & 576000 & 721 & 864 \\
\hline 2 & 1463 & 1007 & 594000 & 1170000 & 1347 & 1711 \\
\hline 3 & 1425 & 1055 & 612000 & 1782000 & 2049 & 2539 \\
\hline 4 & 1388 & 1103 & 630000 & 2412000 & 2829 & 3347 \\
\hline 5 & 1350 & 1151 & 648000 & 3060000 & 3690 & 4131 \\
\hline 6 & 1313 & 1199 & 666000 & 3726000 & 4636 & 4890 \\
\hline 7 & 1275 & 1247 & 684000 & 4410000 & 5667 & 5623 \\
\hline 8 & 1238 & 1295 & 702000 & 5112000 & 6788 & 6326 \\
\hline 9 & 1200 & 1343 & 720000 & 5832000 & 8000 & 6998 \\
\hline
\end{tabular}




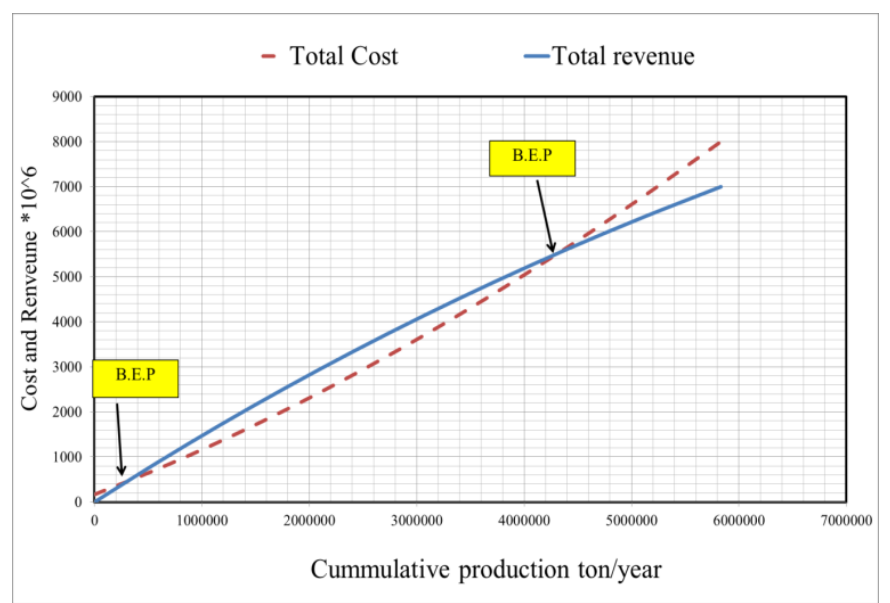

Fig. 8. the Relation between Revenue/Cost and Cumulative Product Ton-Year

$$
\begin{aligned}
& C=7 * 10^{-11} x^{2}+9 * 10^{-4} x+158.45 \\
& R=-5 * 10^{-11} x^{2}+1.5 * 10^{-3} x+7.86
\end{aligned}
$$

\section{Where;}

C: total cost;

R: revenue; ‘

$\mathrm{X}$ : cumulative number of units (tons)

Reduced demand due to purchase power depreciation of the pound is the main factor in decreasing revenue in spite of cumulative profitability. On the other hand, the rise progressively in the cost is predicated as indicated before. Therefore, the production rate can be feasible if the unit saves its production above 576000 ton/ year with sale price not less than, 1200 pound/ ton even if the adaptable cost reaches 1343 pounds.

\section{Conclusions}

Nano materials used in cement plant can develop the construction vision and provide the needs of specialized construction. The impact of Nano cement does not stop at increasing compressive concrete strength but also on saving energy and protecting the environment. The study proves the feasibility of establishing Nano cement unit in existing cement factory through NPV, IRR and BEP value as follow:-

1. The net present value indicates the output of subtracting the total sum of revenues and cost is positive value by (1369.79 Million L.E) at $10 \%$ interest rate and by 436.91 Million L.E) at $30 \%$. This means the project is feasible by interest rate between $10 \%$ and $30 \%$.

2. The internal rate of return reaches $57.55 \%$ which is above the interest rate of central bank of Egypt by $38.80 \%$, this percent shows the cost-effectiveness of Nano cement unit. The project achieves financial return -Breakeven Point- before 1 year of establishing the unit providing that the production line can produce 720000 ton/year.

3. According to the variable cost and revenue, the production rate can be feasible if the unit keeps its production above 576000 ton/ year with sale price not less than 1200 pounds/ ton, even if the adaptable cost in the range of 1343 pound.

4. The planned production shall be in the range of $546000-4200000 \mathrm{t}$ to be a profitable project, this could be achieved within (1-6) years. 
Acknowledgement

The author wishes to express his sincere appreciation to the Construction Research Institute, National Water Research Centre CRI-NWRC, especially Dr. Ehab Badr Eldein Khalil for the encouragement and the financial support they provided.

\section{REFERENCES}

[1] L. Raki, J. Beaudoin, R. Alizadeh, J. Makar, and T. Sato, Cement and concrete nano science and nano technology, Materials 3 , 2010, 918-942.

[2] Russian Federation, Final report of the experimental industrial testing to produce nano cement and concrete on its basis during the period from 29.03.2016 to 24.05.2016, Aktobe city, Republic of Kazakhstan- Moscow city.

[3] P. Sabdonoa, F. Sustiawana, and D. Fadlillaha, The effect of nano-cement content to the compressive strength of mortar, Proceedings of 2nd International Conference on Sustainable Civil Engineering Structures and Construction Materials-2014, 386-395.

[4] M. Bickbau, Capsulation is the principle of composite materials of new generation by nano capsulation, macro capsulation - ultra high strength cement by the method of NanoEncapsulation, IMET Program International Workshop -Conference, Dubai, 2015.

[5] B.F. Ikhlef, Nano cement and concretes on their base test in the, U.S, P.R., Chine, the UAE, Saudi Arabia, Portugal and Brazil, IMET Program International Workshop Conference, Dubai, 2017.

[6] M.Y. Bickbau, Nanocement as the basis of effective modernization of precast concrete plants, J. Concrete Product Structure, No. 1, 2012, 4-38.

[7] M.Y. Bickbau, and V.N. Shykun, Nano Cement Future of World Cement Industry and Concrete Technology, 2015.

[8] H.R. Ashani, S.P. Parikh, and J.H. Markna, Role of nanotechnology in concrete cement based material: a critical review on mechanical properties and environmental impact, Int. J. Nanoscience and Nanoengineering 2, 2015, 32-35.

[9] Moscow IMET, Final Report of the Experimental Industrial Testing to Produce Nano Cement and Concrete on Its Basis, 2016.

[10]F. Lai, S. Kimia Sika, M. Zain, and M. Jamil, Nano cement additives development for OPC strength enhancer and carbon neutral cement, Proceedings of $35^{\text {th }}$ Conference on Our World in Concrete in Structures, Singapore, 2010.

[11]Y.R. Mahajan, Nanotechnology in the Cement Industry, 2012 http://www.nanowerk.com/spotlight/spotid=28101.php (Accessed 15c February 2013).

[12]R.N. Sherve, Silica sand mineral planning fact sheet, Chemical Process Industries, 3rd ed., McGraw Hill, Tokyo, 2004.

[13]B. Jo, J. Choi, and S. Kang, An experimental study on the characteristics of chemically synthesized nano cement for carbon dioxide reduction, J. Ceramic Processing Research 12 (2011) 294-298.

[14] V.N. Shykun, Economy evaluation of the nano cement production management, IMET Program International Workshop - Conference, Dubai, 2015 http://media.wix.com/ugd/457c82 a359b3aa2a594323ada2da8d23993ca7.pdf (Accessed 15 April 2016).

[15] Annual report 2016-2017 of Central Bank of Egypt http://www.cbe.org.eg/ar/EconomicResearch/Publications/Pages/AnnualReport.aspx

[16] Separate interim financial statements for the period ended 30 june 2017 together with review report, Suez Cement Company, 2017.

[17] L.G. Nagalingam, Principle of Finance, CIM, London, 2008.

[18] P.E. Hicks, Industrial Engineering Management a New Perspective, McGraw-Hill, USA, 2008. 


\section{تقييم إنتاج أسمنت النانو للمنشآت الخرسانية في مصر}

\section{الملخص العربى:}

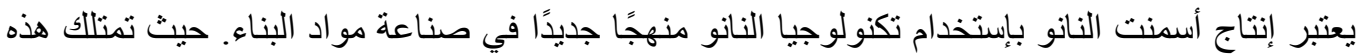
التكنولوجيا القدرة على تقليل حجم جزئيات الأسمنت إلى نطاق النانو مما يزيد من النشاط الكيان الكيميائي للأسمنت.

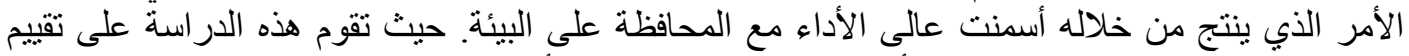

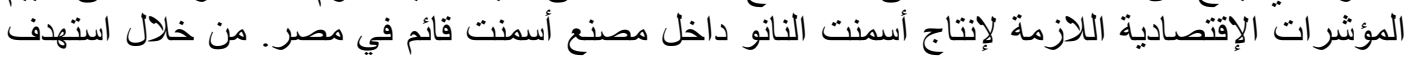

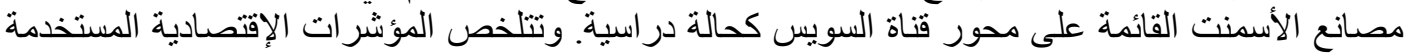

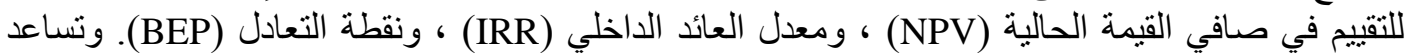

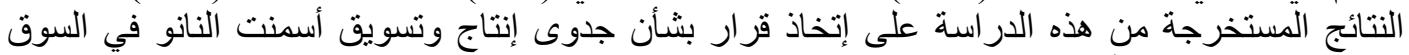

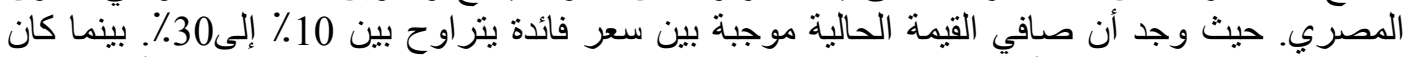

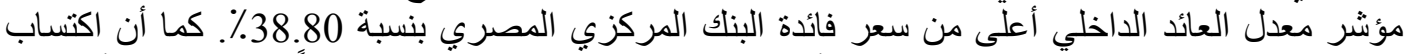

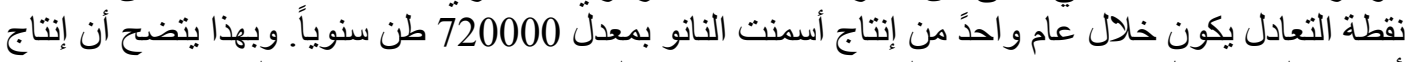

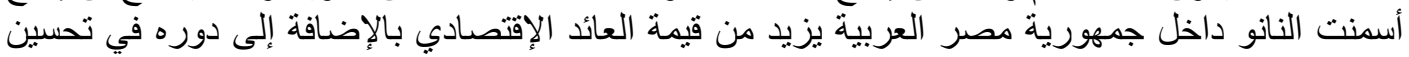
خو اص الخرسانة. 